\title{
THE FAILURE OF FIRE-FIGHTING EQUIPMENT AT FRS ZLÍN REGION
}

\author{
Ladislav JÁNOŠÍK ${ }^{1}$
}

Review article

The paper follows previous work of the author focused on evaluating of operation and
maintenance of fire-fighting equipment on the chassis Mercedes-Benz Atego (Jánošík,
2010a) and TATRA (Jánošík, 2010b) in use at Fire Rescue Service in the Moravian-
Silesian and Hradec Králové Region. The observation results of car fire-engines on the
chassis Renault Midlum in use at Fire Rescue Service Zlín Region with fire trucks by
the Polish supplier Wawrzaszek ISS Ltd., Bielsko-Biala, and by the Czech company
THT Ltd., Polička, are summarized in this paper. Fire Rescue Service of the Zlín Region
consists of four fire departments and is specific with the fact that the fire equipment based
on the observed chassis is allocated at all of the departments.
Reliability in operation; technique operation; service of technique; maintenance of
fire-fighting equipment; Fire Rescue Service of the Zlín Region.

\section{Introduction}

Total coverage of the Zlín region is represented by 13 fire protection units of the Fire Rescue Service of the Czech Republic. A group of 13 vehicles type CAS (fire engine) on the chassis-Renault Midlum was selected to monitor traffic and failure. Overview of selected car is given in Tab. 1 .
To give an idea it is an intervention fire truck with a total weight of 14 tons with an engine power of $195 \mathrm{~kW}$ and measuring approximately $8.0 \times 2.5$ x $3.3 \mathrm{~m}$ (length/ width/height). The average age of monitored vehicles is 6 years. To characterize the workload of the fire-fighting equipment the number of incidents for the years 2007 - 2012 on the monitored fire stations of FRS Zlín Region is shown in Fig 1. (Zavadil, 2013).

Tab. 1 Tracking reports of fire-fighting equipment

\begin{tabular}{|c|c|c|c|c|c|c|}
\hline & $\begin{array}{c}\text { Fire } \\
\text { Station }\end{array}$ & $\begin{array}{l}\text { Identification of the } \\
\text { Vehicle }\end{array}$ & $\begin{array}{l}\text { Registration } \\
\text { Number }\end{array}$ & Chassis & Extension & $\begin{array}{c}\text { Year of } \\
\text { manufacture }\end{array}$ \\
\hline 1 & \multirow[t]{3}{*}{ Zlín } & CAS $24 / 2500 / 250-M 1 T$ & $1 Z 76958$ & Midlum 270.15/14 4x2 & ISS Wawrzaszek & 2004 \\
\hline 2 & & CAS $24 / 2500 / 250-\mathrm{M} 2 \mathrm{~T}$ & $2 Z 78478$ & Midlum 270.14 P 4x4 & ISS Wawrzaszek & 2006 \\
\hline 3 & & CAS 15/2000/120-M2Z & $3 Z 34693$ & Midlum 270.14 P 4x4 & THT Polička & 2007 \\
\hline 4 & Slavičín & CAS 15/2200/150-M2Z & $3 Z 57550$ & Midlum 270.14 P 4x4 & THT Polička & 2008 \\
\hline 5 & Otrokovice & CAS $24 / 2500 / 250-\mathrm{M} 2 \mathrm{~T}$ & $2 Z 78479$ & Midlum 270.14 P 4x4 & ISS Wawrzaszek & 2006 \\
\hline 6 & \multirow{3}{*}{$\begin{array}{l}\text { Valašské } \\
\text { Meziříčí }\end{array}$} & CAS 24/2500/250-M2T & $2 Z 62647$ & Midlum 270.14 P 4x4 & ISS Wawrzaszek & 2005 \\
\hline 7 & & CAS 15/2200/135-S2Z & $3 Z 57540$ & Midlum 270.14 P 4x4 & THT Polička & 2008 \\
\hline 8 & & CAS 15/2000/120-M2Z & $3 Z 34692$ & $\begin{array}{c}\text { Midlum Medium } 4 \mathrm{x} 4 \text {, } \\
240.14 \mathrm{P}\end{array}$ & THT Polička & 2008 \\
\hline 9 & $\begin{array}{l}\text { Uherský } \\
\text { Brod }\end{array}$ & CAS 20/2500/300-M2T & $3 Z 23957$ & $\begin{array}{c}\text { Midlum Medium } 4 \times 4 \text {, } \\
280.14 \mathrm{P}\end{array}$ & ISS Wawrzaszek & 2007 \\
\hline 10 & $\begin{array}{l}\text { Uherské } \\
\text { Hradiště }\end{array}$ & CAS 20/2500/250-M2T & $3 Z 66297$ & Midlum 280.14 4x4 & ISS Wawrzaszek & 2008 \\
\hline 11 & \multirow[t]{2}{*}{ Kroměříž } & CAS $24 / 2500 / 250-M 2 T$ & $2 Z 62649$ & Midlum 270.14 P 4x4 & ISS Wawrzaszek & 2005 \\
\hline 12 & & CAS $24 / 2500 / 250-M 1 T$ & $1 Z 76957$ & Midlum 270.15/14 P 4x2 & ISS Wawrzaszek & 2004 \\
\hline 13 & $\begin{array}{l}\text { Morkovice - } \\
\text { Slížany }\end{array}$ & CAS $24 / 3500 / 200-\mathrm{M} 2 \mathrm{~T}$ & $1 Z 68059$ & $\begin{array}{l}\text { Midlum Medium } 4 x 4 \text {, } \\
220.14 \mathrm{P}\end{array}$ & ISS Wawrzaszek & 2004 \\
\hline
\end{tabular}

VŠB - Technical University of Ostrava, Faculty of Safety Engineering, Ostrava, Czech Republic, ladislav.janosik@vsb.cz 


\section{Materials and methods}

The Order of mechanical services (Note, 2006) regulates the operation records of the fire-fighting equipment. Each responsible worker of the machine service at the station has a duty to monitor traffic data and vehicle maintenance at each individual station.

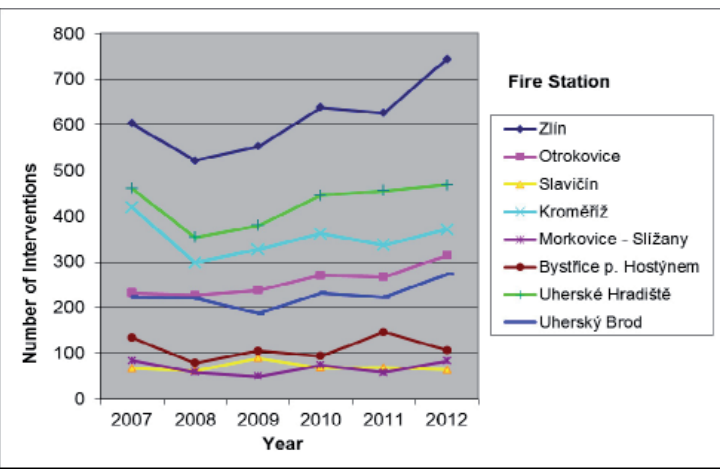

Fig. 1 Fire brigade intervention of the Zlín Region

Work records of the fire-fighting equipment are kept in the journey report and include the date, purpose of journey, current mileage and final mileage, number of working hours (engine hours), refueling and filling fluids, service activities, operation or repair costs and the time during which is the vehicle out of service.
Operational diaries of vehicles kept in a paper form were previously used for this purpose. From 2010, IKIS electronic information system serves this purpose, which forms a central database of vehicles of FRS of the Czech Republic. The necessary data were obtained from this system for the analysis of vehicles operation from their operation start until 30. 9. 2012. Incomplete information about operation was found during processing especially before 2010 , where for example data were missing for the whole month. This was primarily affected by the activities of engineers and omitting data on transcription from paper to electronic form during the year 2009. For example in Tab. 2 are given processed and sorted data on the operation and maintenance of two vehicles at the busiest station in Zlín.

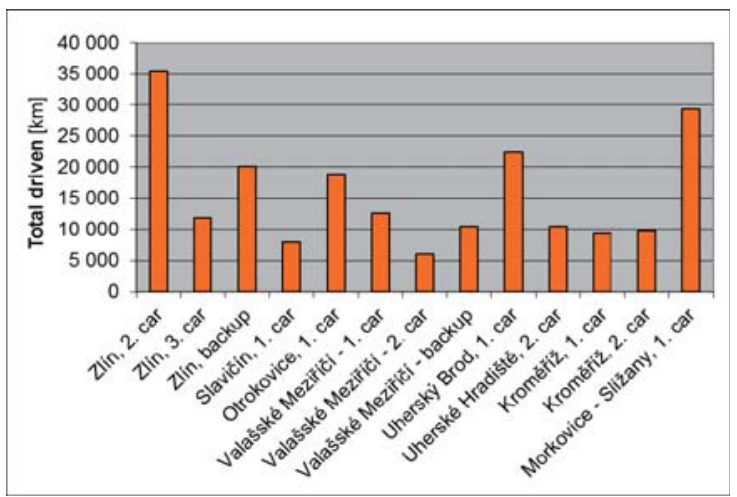

Fig. 2 The total kilometric run over

Tab. 2 Overview of operation of selected cars at the Fire station Zlín

\begin{tabular}{|c|c|c|c|c|c|c|c|c|c|c|c|}
\hline 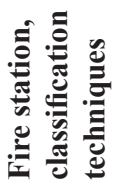 & 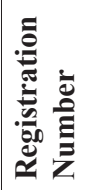 & 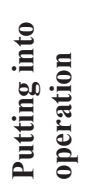 & 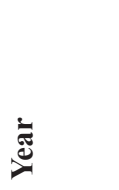 & 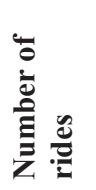 & 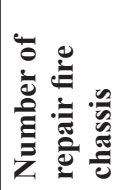 & 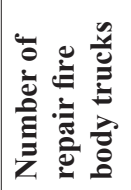 & 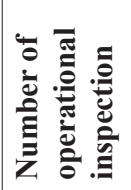 & 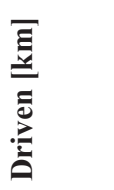 & 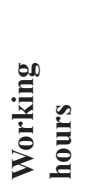 & 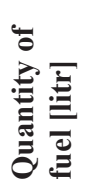 & 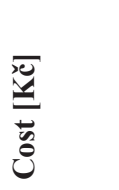 \\
\hline \multirow{9}{*}{ 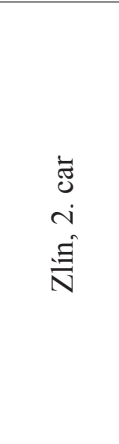 } & \multirow{9}{*}{$\begin{array}{l}\infty \\
2 \\
\hat{\sigma} \\
\hat{N}\end{array}$} & \multirow{9}{*}{ 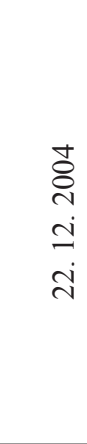 } & 2005 & 0 & 1 & 1 & 0 & 5123 & 102 & 0 & 0 \\
\hline & & & 2006 & 0 & 2 & 0 & 2 & 4596 & 92 & 0 & 0 \\
\hline & & & 2007 & 0 & 2 & 0 & 2 & 5761 & 115 & 0 & 1450 \\
\hline & & & 2008 & 0 & 2 & 0 & 2 & 4340 & 87 & 0 & 270 \\
\hline & & & 2009 & 0 & 1 & 0 & 2 & 3900 & 78 & 0 & 0 \\
\hline & & & 2010 & 269 & 15 & 6 & 3 & 4618 & 83 & 1684 & 75412 \\
\hline & & & 2011 & 279 & 9 & 14 & 5 & 3972 & 92 & 1580 & 74830 \\
\hline & & & 2012 & 217 & 9 & 8 & 4 & 3231 & 54 & 1145 & 73522 \\
\hline & & & celkem & 765 & 41 & 29 & 20 & 35541 & 703 & 4408 & 225484 \\
\hline \multirow{8}{*}{$\begin{array}{l}\dot{\Xi} \\
\dot{0} \\
\dot{N} \\
\dot{\bar{N}}\end{array}$} & \multirow{8}{*}{\begin{tabular}{l}
$\infty$ \\
\multirow{+}{*}{} \\
N
\end{tabular}} & \multirow{8}{*}{$\begin{array}{l}\text { \& } \\
\text { ते } \\
\dot{2} \\
\dot{2}\end{array}$} & 2006 & 0 & 0 & 0 & 0 & 2032 & 0 & 0 & 0 \\
\hline & & & 2007 & 0 & 0 & 0 & 2 & 5100 & 0 & 0 & 0 \\
\hline & & & 2008 & 0 & 0 & 0 & 3 & 3217 & 0 & 0 & 0 \\
\hline & & & 2009 & 0 & 2 & 2 & 2 & 3406 & 0 & 0 & 0 \\
\hline & & & 2010 & 298 & 12 & 4 & 4 & 4413 & 96 & 1968 & 85128 \\
\hline & & & 2011 & 192 & 9 & 8 & 4 & 3354 & 66 & 1466 & 179744 \\
\hline & & & 2012 & 220 & 6 & 8 & 3 & 4144 & 54 & 1556 & 92078 \\
\hline & & & celkem & 710 & 29 & 22 & 18 & 25666 & 215 & 4990 & 356950 \\
\hline
\end{tabular}


Fig. 2 summarizes the characteristics of vehicles operation in terms of mileage $\mathrm{km}$. In the total vehicles mileage were considered all types of rides i.e. intervention, economic and training. The average annual mileage of $2700 \mathrm{~km}$ was calculated from the obtained values.

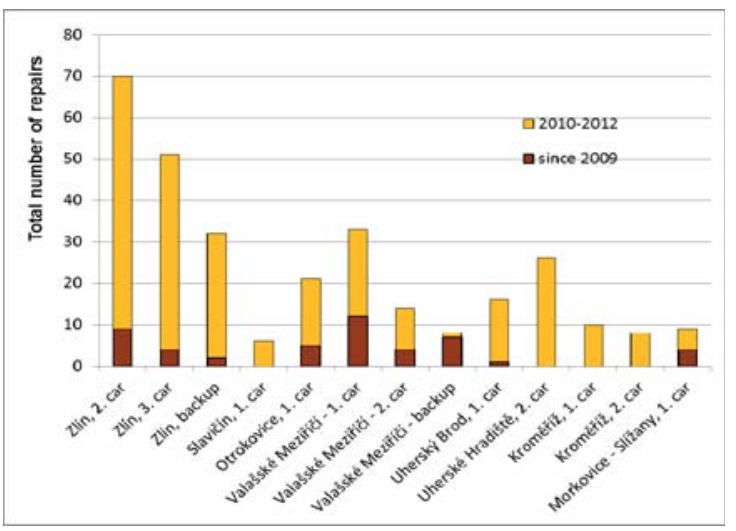

Fig. 3 The total number of repairs

Fig. 3 summarizes the results of the analysis of failures with respect to the reporting period. There are separate data by the end of 2009 , when records were kept in a paper form and from 1st January 2010 which has already been recorded in the electronic system.

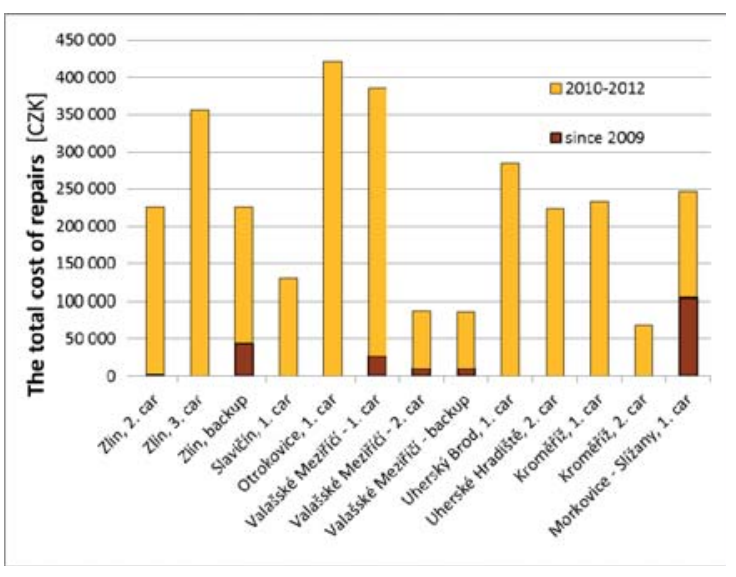

Fig. 4 The total cost of repairs

Fig. 4 in addition in the same way summarizes the total costs of vehicles repair. The increase in the number of recorded failures and thus the repair costs from 1. 1. 2010 does not mean in any case that vehicles had more failures due to the change of evidence records of their operations. This hypothesis will be supported by the conclusion.

\section{Results}

To calculate the operating characteristics a method called test plan was selected (Famfulík, 2010). The method of test plan can determine the mean time to failure by a small group of products. If we wanted to verify the entire series and we waited for a fault at all pieces, then we came to the conclusion that we made the destruction of all pieces or waited for an unreasonable time to failure. For these reasons this test is performed only on a limited number of products in advance and if necessary limited to the period of its duration or the number of failures.

To evaluate the failure rate a test plan was selected limited by the time to failure called $t$ - plan. The limit of this test is its duration and a random variable is the number of recorded failures. Prerequisite for the test is that the products will be repaired after the failure. The time variable representing the course of the exam is the accumulated working time $T_{A K U}$, which is the total time during which all the products were in operation while testing. The accumulated working time for the selected $t$ - plan is calculated according to the equation:

$$
T_{A K U}=\Sigma\left(\tau_{0}-\theta_{i}\right)+(n-r) \cdot \tau_{0}
$$

where

$\tau_{0} \quad$ test time, from beginning till occurrence $r_{0}$ such failure,

$n$ number of products included in the test,

$r$ number of faulty pieces,

$\theta_{i} \quad$ the time required to repair the $i$ - th product.

To calculate the operating characteristics by the $t$ - plan method time to failure was calculated in monitored vehicles.

Due to the availability and verifiability of the input data of the monitored vehicles their operation was rated from 1. 1. $2010-31.9 .2012$. With regard to the data accuracy, the mileage and odometer reading were only considered at the time of failure by calculating the time to failure.

The test time limit $\tau_{0}$ was established for the limits 1000, 2000, 3000 and $4000 \mathrm{~km}$, which roughly correspond to the annual vehicles mileage. These limits were subsequently converted into time by dividing the distance traveled in kilometers at an average speed of $50 \mathrm{~km} / \mathrm{h}$, which is the value with which the FRS of the Czech Republic standardly works. A calculation was subsequently performed according to equation (1) and the calculated accumulated time then back converted into kilometers.

The results of the calculations obviously proved that a fault occurs on the vehicle even before reaching the mileage. The results of calculations of times to failure, depending on the limit for the test period are shown in the graph in Fig. 5. 


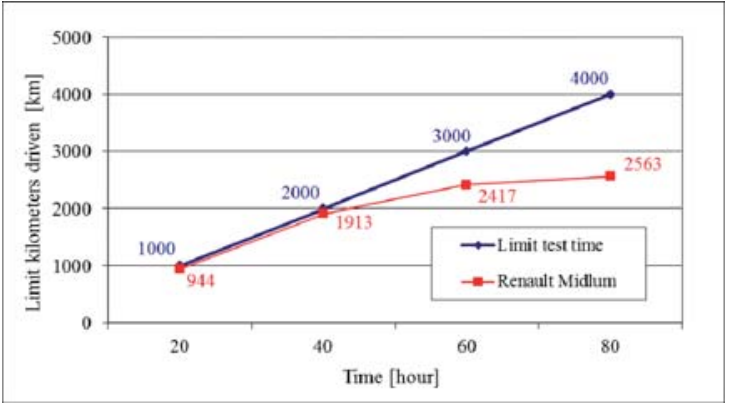

Fig. 5 Times to failure of Renault Midlum vehicles

\section{Discussion}

The difference between the marginal test time and the calculated average value, in which a fault occurs, increases with increasing test time. This is obviously due to the fact that during a longer period of time failure occurs on more vehicles. Failure rate for individual vehicles affects the period during which the vehicles are included in outgoing activities and also their workload. The fact, that tracked vehicles are not absolutely identical and in operation for variously long time (from the year of manufacture 2004 till 2008) and with different workloads, undoubtedly distorts the results. Under the current conditions of operation record of fire-fighting equipment seems to me practically impossible to achieve the ideal condition for reliability calculation of FRC vehicles of the Czech Republic.

The first reason is the diversity of techniques resulting from its continuous development and innovation. The other significant reason is collection of input data,

\begin{tabular}{|c|c|c|c|c|c|}
\hline & & & $\begin{array}{l}\text { Renault } \\
\text { Midlum }\end{array}$ & $\begin{array}{c}\text { Mercedes-Benz } \\
\text { Atego }\end{array}$ & $\begin{array}{c}\text { TATRA } \\
\text { TERRN }^{\circ} 1\end{array}$ \\
\hline Number of vehicles & \multicolumn{2}{|r|}{ [piece] } & 13 & 11 & 8 \\
\hline Oldest vehicle & \multicolumn{2}{|r|}{ [year] } & 9 & 10 & 18 \\
\hline Youngest vehicle & \multicolumn{2}{|r|}{ [year] } & 5 & 5 & 5 \\
\hline Average time in use & \multicolumn{2}{|r|}{ [year] } & 7 & 9 & 11 \\
\hline \multirow{3}{*}{$\begin{array}{l}\text { Average kilometric } \\
\text { run over }\end{array}$} & \multirow{3}{*}[\mathrm{km}]{} & 2010 & 3130 & 5479 & 3522 \\
\hline & & 2011 & 2907 & 4620 & 3421 \\
\hline & & do 30.9 .2012 & 2831 & 3968 & 3425 \\
\hline \multirow{4}{*}{$\begin{array}{l}\text { The total number } \\
\text { of failures }\end{array}$} & \multirow{4}{*}{ [piece] } & 20 hod & 7 & 8 & 3 \\
\hline & & 40 hod & 12 & 12 & 8 \\
\hline & & 60 hod & 21 & 14 & 12 \\
\hline & & 80 hod & 37 & 22 & 20 \\
\hline
\end{tabular}
especially their availability and in some cases "hand" evidence and their completeness.

\section{Conclusion}

In the next step the vehicles data on the chassis Mercedes-Benz Atego of the Moravian-Silesian Region and the vehicles on the chassis TATRA TERRN $^{\circ} 1$ of the Hradec Králové region were due to a comparison updated and processed for the years 2010 and 2012. The calculation results are shown in Fig 6.
Before the reader makes a clear conclusion it should be noted that for vehicles TATRA TERRN ${ }^{\circ} 1$, the input data were provided by the extract of operational logs carried out by a machinery service member of Hradec Králové Region, where a program IKIS has been used only marginally, while by the vehicles on the chassis Mercedes-Benz Atego the data was exported from the electronic information program IKIS.

Fig. 6 Compared time to failure

Tab. 3 Comparison of techniques and their operational parameters

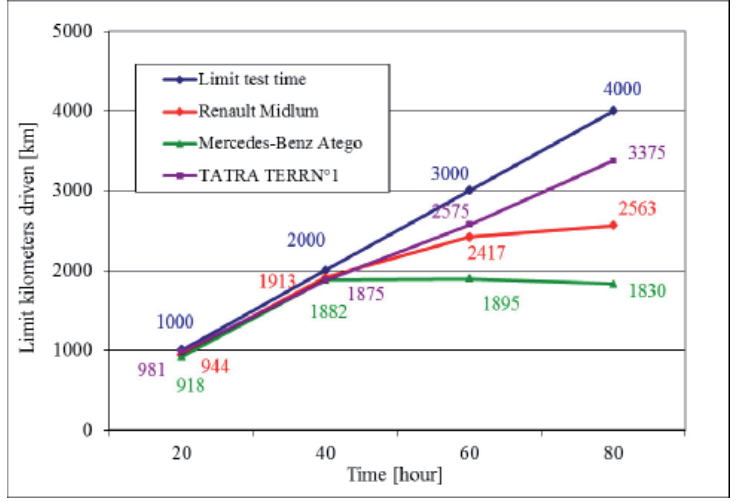

We can state with a slight exaggeration that there is rather a statement in comparing the results of accurate records for vehicles Renault and Mercedes-Benz versus "hand" evidence in the case of vehicles TATRA. To illustrate the comparison of fire trucks to tracked chassis Tab. 3 summarizes their basic operating data.

With regard to the "hand" extract of vehicles service and the calculation results which are shown in Fig. 6 you can't help thinking that by the TATRA vehicles were not provided all information about faults and probably were "left out" those faults that were not considered important or were not recorded 
at all. In the stated figure can be seen almost linear time to failure, which copies the limits test period, compared to realistically falling curves of the two other types of vehicles. In addition, the vehicles tracking TATRA were the oldest age and were not provided any information about any of their refurbishment.

\section{References}

FAMFULÍK, Jan, KRZYŽÁNEK, Radek, GALVAS, Peter (2010). Zkoušky spolehlivosti: Vybrané stochastické metody. 1. vyd. Ostrava: VŠB - Technická univerzita Ostrava, 2010, 67 p. ISBN 978-80-248-2277-8. (in Czech)

JÁNOŠÍK, Ladislav, PIKA, Martin, MONOŠI, Mikuláš (2010). Provozní spolehlivost vozidel Mercedes-Benz Atego. Transactions of the V̌́B-Technical University of Ostrava, Safety Engineering Series. 2010, Vol. V, No. 2, pp. 61-69. ISSN 1801-1764. (in Czech)

JÁNOŠÍK, Ladislav, MELICHAR, David (2010). Provozní spolehlivost vozidel TATRA. In: Požární ochrana 2010: XIX. ročník mezinárodní konference. Ostrava: Sdružení požárního a bezpečnostního inženýrství, 2010, pp. 115-118.. ISBN 978-80-7385-087-6. (in Czech)

Life Data Analysis Reference Book (2013). Tucson: ReliaSoft Corporation [online] [cit. 2013-10-09]. Available at: $<$ http://reliawiki.org/index.php/Life_Data_Analysis_Reference_Book>

Pokyn č. 9 generálního ředitele HZS ČR a náměstka MV ze dne 13. 3. 2006, kterým se vydává Řád strojní služby Hasičského záchranného sboru České republiky. (in Czech)

ZAVADIL,Luděk(2010).Statistickéročenkyzásahovéčinnostijednotekpožárníochrany[online].Zlín:HZSZlínského kraje, 2010 [cit. 2013-12-10]. Available at: <http://archiv.hzszlk.eu/data/file_downloads/SR_2012.pdf>. (in Czech) 